University of Nebraska - Lincoln

DigitalCommons@University of Nebraska - Lincoln

USDA Wildlife Services - Staff Publications

U.S. Department of Agriculture: Animal and

Plant Health Inspection Service

8-31-2006

Fences and Deer-Damage Management: A Review of Designs and Efficacy

Kurt C. VerCauteren

USDA-APHIS-Wildlife Services, kurt.c.vercauteren@usda.gov

Michael J. Lavelle

USDA/APHIS/WS National Wildlife Research Center, michael.j.lavelle@aphis.usda.gov

Scott Hygnstrom

University of Nebraska-Lincoln, shygnstrom1@unl.edu

Follow this and additional works at: https://digitalcommons.unl.edu/icwdm_usdanwrc

Part of the Environmental Sciences Commons

VerCauteren, Kurt C.; Lavelle, Michael J.; and Hygnstrom, Scott, "Fences and Deer-Damage Management: A Review of Designs and Efficacy" (2006). USDA Wildlife Services - Staff Publications. 99.

https://digitalcommons.unl.edu/icwdm_usdanwrc/99

This Article is brought to you for free and open access by the U.S. Department of Agriculture: Animal and Plant Health Inspection Service at DigitalCommons@University of Nebraska - Lincoln. It has been accepted for inclusion in USDA Wildlife Services - Staff Publications by an authorized administrator of DigitalCommons@University of Nebraska - Lincoln. 


\title{
Fences and Deer-Damage Management: A Review of Designs and Efficacy
}

\author{
KURT C. VerCAUTEREN, ${ }^{1}$ United States Department of Agriculture/Animal and Plant Health Inspection Service/Wildlife Services/National Wildlife \\ Research Center, Fort Collins, CO 80521-2154, USA \\ MiCHAEL J. LAVELLE, United States Department of Agriculture/Animal and Plant Health Inspection Service/Wildlife Services/National Wildlife Research \\ Center, Fort Collins, CO 80521-2154, USA \\ SCOTT HYGNSTROM, School of Natural Resources, University of Nebraska, Lincoln, NE 60583-0819, USA
}

\begin{abstract}
White-tailed deer (Odocoileus virginianus) may cause more damage than any other species of wildlife. These damages include crop loss, automobile and aviation collisions, disease transmission, environmental degradation, and destruction of ornamental plantings. One practical method of controlling deer damage is the use of exclusionary fences. The relatively high cost of labor and materials required to build effective fences has limited most applications to the protection of orchards, vegetable farms, other high-value resources, and mitigation of human health and safety risks. Improvements in fence technology resulting in less expensive, yet effective fences have expanded the use of fences to manage damage caused by deer. Fences typically installed to manage white-tailed deer damage include wire or plastic mesh, electrified high-tensile steel wire, and electrified polytape or polyrope fence. We reviewed the scientific literature on fencing to determine which fence designs would be the most effective for excluding deer in a variety of situations. (WILDLIFE SOCIETY BULLETIN 34(1):191-200; 2006)
\end{abstract}

\section{Key words}

barrier, exclusion, fence, Odocoileus virginianus, white-tailed deer, wildlife damage management.

A variety of fences have been used throughout history to control the movements of animals and reduce the damage they might cause. In South Africa indigenous people used a series of holes and dirt mounds to repel bush pigs (Potamochoerus larvatus) and rows of sharpened spears to exclude small antelope from crops (Fitzwater 1972). Australians have extensively used "vermin" exclusion fences to reduce crop damage for nearly 150 years, including rabbit fences spanning several thousand kilometers (McKnight 1969).

In the mid-1930s, wildlife managers used fences to minimize the spread of disease in wildlife populations. In Florida, in an attempt to eliminate cattle fever-infected ticks from being spread by white-tailed deer (Odocoileus virginianus) wildlife managers constructed $128 \mathrm{~km}$ of 6-strand electrified barbed-wire fence (McAtee 1939). More recently, outbreaks of bovine tuberculosis (Schmitt et al. 1997), chronic wasting disease (Miller et al. 1998), and brucellosis (Rhyan 2000) have reemphasized the need for methods to reduce the potential for disease transmission between domestic and wild animals.

Common fence designs used to contain livestock typically include 3- to 6-strand barbed wire and single- and multi-strand electric wire. Also, buck, post and rail, and stockade type fences are still used to contain livestock. While these fence designs are effective for livestock, they do not exclude white-tailed deer. Our goal is to explain the use of deer fences, describe the types of fences available, and define situations where fencing is an economically viable means of controlling damage caused by deer. We review and expand upon the literature to take into consideration the value of the commodity or resource being protected, level of motivation required for deer to penetrate the fence, and characteristics of specific fence types (i.e. cost, longevity, maintenance). Our effort included a key word search

${ }^{1}$ E-mail: kurt.c.vercauteren@aphis.usda.gov of all available on-line agricultural and biological abstract databases. Reference to trade names does not imply United States government endorsement of commercial products or exclusion of similar products.

\section{Deer Damage Issues}

Agricultural producers generally tolerate approximately $\$ 500$ to $10 \%$ crop loss (whichever comes first) in wildlife damage (Craven et al. 1992, Craven and Hygnstrom 1994). Crop losses caused by white-tailed deer exceed losses associated with all other wildlife species in the United States (Conover and Decker 1991). In the top 10 corn-producing states, deer damage exceeded $\$ 21$ million in 1993 (Wywialowski 1996). Isleib (1995) estimated that annual crop losses to deer in the Upper Peninsula of Michigan exceeded $25 \%$ of all field and forage crops grown. In New York an average annual loss of $\$ 15,000$ /orchard is common (Purdy et al. 1987). Until the late 1980s, many growers used repellents such as bars of soap and bags of predator hair; exclusionary fences were used by only 1 in 6 producers (Phillips et al. 1987, Purdy et al. 1987).

Many state governments provide compensation for damage caused by deer (Caslick 1980, Craven 1983, Byrne 1989) or issue depredation permits to allow for the removal of depredating animals (Bartlett and Boyce 1954, Caslick 1980, Craven 1983). Further, some government agencies provide assistance to landowners for constructing deer-exclusionary fences (e.g., The Wisconsin Wildlife Damage Abatement and Claims Program [Craven 1983, Fagerstone and Clay 1997]). Besides fences and repellents, other methods used to control damage by deer include habitat modification (e.g., lure crops), live trapping and translocation, fertility control, frightening devices (e.g., scarecrows), and lethal control (e.g., hunting). In many cases, fence costs were presumed too high to be profitable or were considered incompatible with other land uses (Tanner and Dimmick 1983). 
Table 1. Comparison of a variety of fences for managing damage caused by deer and their characteristics including: cost (including labor), efficacy, longevity, and maintenance.

\begin{tabular}{|c|c|c|c|c|c|}
\hline Fence type & Cost/m (\$) & Height (m) & Efficacy (\%) & Longevity (yrs) & Maintenance \\
\hline Woven wire & $10.00-15.00$ & 2.40 & 90-99 & $30-40$ & Low \\
\hline Welded wire & $10.00-15.00$ & 2.40 & $90-99$ & $20-30$ & Low \\
\hline Chain link & $>20.00$ & 2.40 & $90-99$ & $30-40$ & Low \\
\hline Poly. mesh & $15.00-20.00$ & 2.40 & $90-99$ & $10-20$ & Medium \\
\hline Poly. rope 9 & $5.00-10.00$ & 1.82 & $70-80$ & $15-25$ & High \\
\hline Mod. WW $3 \mathrm{HT}^{\mathrm{a}}$ & $5.00-10.00$ & 2.40 & $80-90$ & $20-30$ & Medium \\
\hline Poly. snow & $5.00-10.00$ & 2.12 & $80-90$ & $15-25$ & Medium \\
\hline Offset HT & $2.00-5.00$ & 1.05 & $60-70$ & $20-30$ & High \\
\hline Slanted $7 \mathrm{HT}^{\mathrm{C}}$ & $2.00-5.00$ & 1.50 & $70-80$ & $20-30$ & High \\
\hline Penn St. 5 HT & $2.00-5.00$ & 1.12 & $70-80$ & $20-30$ & High \\
\hline Poly. tape $2^{d}$ & $<2.00$ & 0.90 & $60-70$ & $5-15$ & High \\
\hline Baited electric & $<2.00$ & 1.12 & 80-90 & $10-20$ & High \\
\hline
\end{tabular}

\footnotetext{
${ }^{\text {a }}$ Modified woven-wire fence with 3 strands of high-tensile wire above.

${ }^{b}$ Polypropylene snow fence.

c Slanted 7-strand high-tensile wire.

d Two-strand poly-tape.
}

Deer collisions with automobiles and aircraft threaten human health and safety and cause substantial economic damage. In 1991 $>538,000$ deer were killed in deer-vehicle collisions (DVCs) in the United States (Lehnert and Bissonette 1997). Conover (2002) estimated that DVCs cost approximately $\$ 1.6$ billion annually. In areas where DVCs are concentrated on short stretches of highway, fencing was the most economical and effective solution (Bashore et al. 1985). Dolbeer et al. (2000) determined that deer were the most hazardous wildlife species on airport runways, causing an estimated $\$ 85,093$ damage/aircraft collision.

White-tailed deer carry and spread diseases to other wild and domestic animals including humans (DeNicola et al. 2000). Infectious diseases of deer such as chronic wasting disease (CWD), bovine tuberculosis, and Lyme disease are relatively new or re-emerging in deer herds across North America. Chronic wasting disease is a prion disease of elk (Cervus elaphus nelsoni), white-tailed deer, mule deer (O. hemionus), and moose (Alces alces) and is reported to be transmitted through direct contact as well as other means (Miller et al. 2004). Bovine tuberculosis is a bacterial disease that has become established in wild white-tailed deer herds in northern Michigan and can be readily transmitted to cattle through direct contact or environmental contamination (Kaneene et al. 2002). White-tailed deer also serve as a host for the primary vector of Lyme disease (the black-legged tick, Ixodes scapularis). Reducing concentrations of deer can reduce the occurrence of Lyme disease in humans (Kilpatrick and LaBonte 2003). Additionally, fences could be used as barriers to slow the spread of diseases transmitted by deer. We suggest that, because densities of deer are at record levels in many areas, potential for large-scale outbreaks of disease exist (VerCauteren 2003).

Fences exclude or contain animals by providing a physical barrier, a psychological barrier (via behavioral conditioning), or a combination of both. Some fences such as woven-wire present a physical barrier, preventing animals from passing over, through, or under. Conversely, a 2-strand electric polytape fence provides a minimal physical barrier but acts as a psychological barrier through the delivery of negative stimuli (shock) upon contact (McKillop and Sibly 1988, Curtis et al. 1994). Other fences, like electrified 15-strand high-tensile wire, achieve both results.
Though fences can be a reliable solution to deer damage in many situations, there are some consequences of using fencing. When deer are excluded from feeding in an agricultural field, they may simply shift to nearby unprotected areas (Isleib 1995). Additionally, the habitat lost through the exclusion of areas that were previously accessible may concentrate deer on smaller areas, potentially magnifying existing damage or exacerbating disease transmission. Travel corridors that once crossed agricultural fields may be re-routed to right-of-ways along highways, thus increasing the potential for DVCs.

\section{Fencing Considerations}

Several variables must be considered when determining types of deer-exclusion fence to use. These variables include desired level and duration of protection, ability of deer to penetrate various designs, deer motivation to penetrate, behavioral characteristics of deer, economics, and the possible negative effects of fences.

\section{Level of Protection}

The desired level and duration of protection is a primary consideration. A fence that is $50-60 \%$ effective may be adequate for some situations, such as reducing damage in large corn fields. For example, a farmer losing $10 \%$ of his corn crop to deer could reduce that loss to an acceptable $5 \%$ with the installation of an inexpensive fence that is $50 \%$ effective. The same fence, however, would not be appropriate in a situation where deer intrusions could not be tolerated, such as areas where deer may transmit diseases to livestock (VerCauteren et al. unpublished data).

Many fences are erected as long-term installations, providing protection for $>30$ years with regular maintenance (Table 1 ). Damage typically occurs seasonally and is related to feeding (Flyger and Thoerig 1962) or breeding-season behaviors (Marsh et al. 1990). When long-term protection is not necessary, a variety of temporary fence designs, such as polytape and polypropylene snow fence may be effective. They are typically less expensive but also are less durable than permanent fences and more prone to fire damage than permanent fences (G. Wright, The Wright Place, personal communication). 


\section{Physical Capabilities}

When attempting to exclude or contain an animal, its size, intelligence, and physical ability must be considered (Fitzwater 1972). In most cases, a 2.4-m fence design will exclude nonstressed deer on level ground (Fitzwater 1972, Falk et al. 1978, Duffy et al. 1988); however, running, stressed deer are capable of making this jump (Arnold and Verme 1963, Sauer 1984). This suggests that a $3.0-\mathrm{m}$ wire-mesh fence may be more appropriate in rough terrain where slope may decrease the overall effective height of a fence or complete exclusion is required (Kaneene et al. 2002).

Deer are not only adept at jumping barriers but are likely to maneuver through or under poorly constructed fences (Feldhamer et al. 1986). Openings in fences that appear small enough to impede deer may actually be large enough for a motivated deer. A $25-\mathrm{cm}$ gap at the bottom of a fence provides adequate passage for an adult white-tailed deer (Falk et al. 1978, Palmer et al. 1985, Feldhamer et al. 1986). Ward (1982) reported that a $15-\mathrm{cm}$ gap under a fence was enough to allow passage of mule deer and Feldhamer et al. (1986) documented deer in Pennsylvania passing through openings as narrow as $19 \mathrm{~cm}$.

\section{Motivating Factors}

The motivating factor, whether food, predators (including humans), seasonal movement, or other, is an important consideration in determining the efficacy of a fence design. The more motivated a deer is to penetrate a fence, the more substantial the fence needs to be (Goddard et al. 2001). Stressed deer are driven to nontypical behaviors and, under certain circumstances (e.g., being pursued by a hunter), they will penetrate a fence that would normally deter them (Bryant et al. 1993, Conover 2002).

If food is abundant and competition minimal, deer will be less motivated to penetrate the barrier, making even a low fence effective (DeNicola et al. 2000). A $25-\mathrm{cm}$ single-strand electric wire fence was effective in excluding deer from a newly seeded area, presumably due to minimal motivation (Steger 1988). Deer with slightly more motivation were excluded from a 4-ha melon planting with the use of a 97-cm, 4-strand electric fence, resulting in the producer's first harvestable crop (McAninch 1986). Conversely, if competition for food exists, then individuals will try harder to penetrate a fence to access the limited resource.

\section{Deer Behavior}

Deer are intelligent animals that learn from observing others (Kinsey 1976). Therefore, as individual deer learn how to penetrate a fence, prompt culling of these individuals may be required for the fence to remain effective (Bartlett and Boyce 1954, McKillop and Sibly 1988). Kinsey (1976) observed that when several fawns penetrated an electric fence, adults that were previously deterred learned to penetrate the fence as well. Beringer et al. (2003) reported similar observations with a fence constructed of monofilament lines. They theorized that the older, "trained" deer lost respect for the fence after seeing others successfully cross it. Conversely, learned behavior can also be beneficial in educating other deer to respect a fence. Kinsey (1976) reported that on several occasions when 1 deer received a shock from an electric fence and instantly retreated, accompanying deer retreated as well. Gallagher and Prince (2003) also demonstrated the learning potential of deer through the successful use of an audible cue reinforced by a shock in the reduction of corn consumption from a feeder.

In agricultural environments a fence should be installed before routine damage begins and preferably before crops become established (Craven and Hygnstrom 1994, Curtis et al. 1994). Travel routes and home ranges of deer will be altered by the new boundary (Owen and Owen 1980, Clevenger et al. 2001), and they will test it thoroughly (Foster and Humphrey 1995). Fences are most likely to be tested and damaged the first few weeks following their installation, emphasizing the need for frequent inspections (McKillop and Sibly 1988). Regular inspections and maintenance are required to successfully exclude deer as they will quickly locate and take advantage of faults in a fence (Ward 1982, Clevenger et al. 2001, Conover 2002).

Fence placement in relation to adjacent habitat should also be considered. Puglisi et al. (1974) reported that deer were more likely to jump fences bordering forested areas than open areas, presumably to access more abundant food adjacent to a roadway. As distance from fence to forest increased, the likelihood of deer jumping the fence decreased.

\section{Economics}

When weighing the merits of installing a fence to control deer damage, the cost relative to potential savings the fence might provide should be considered. Although fences can reduce crop damage, agricultural fields may be too large to make fencing a cost-effective option (Hygnstrom and Craven 1988). Where losses to white-tailed deer are high, farmers often have been advised to grow crops that do not attract deer or even to discontinue farming (Loomis 1975). Expensive fences may be justifiable for only highvalue crops (e.g., Christmas trees, orchards, nurseries, vegetable farms), (Caslick and Decker 1979, Hygnstrom and Craven 1988). For example, Caslick and Decker (1979) found that in apple orchards the potential annual savings after installing a fence could reach or exceed $\$ 10,000$, making it an economically feasible alternative.

The lifespan of a fence in relation to cost also is important when determining economic feasibility. A less expensive fence may require more maintenance and may not last as long as a fence that requires a higher initial investment (Byrne 1989), (Table 1). Although all fences require regular maintenance to remain effective, inexpensive fences like the baited electric require additional maintenance in application of attractants or repellents.

Net present values (NPV) can be used to determine which type of fence, if any, would be cost effective. The NPV compares the value of a dollar today to its value in the future and is an efficient way to measure the benefits and costs that accrue over the lifetime of a particular fence design. The average annual loss to deer should be weighed against costs of installing and maintaining various fence designs over their lifespans.

The relationships between size and shape of the area being fenced, and how they affect total costs, also should be considered. Larger areas are more cost effective to fence than smaller areas because, as the perimeter length increases, the area enclosed increases to a greater degree (Fig. 1A), (Brenneman 1983, McAninch et al. 1983). Further, square areas are more cost effective (lower cost/unit area) to fence than elongated and oddly shaped areas of the same size 


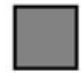

Perimeter $=4$

Area $=1$

$\mathrm{P} / \mathrm{A}=4$

A

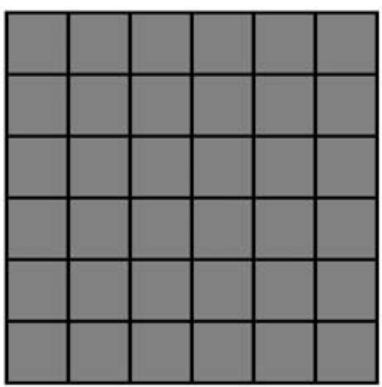

Perimeter $=24$

Area $=36$

B

$\mathrm{P} / \mathrm{A}=0.67$

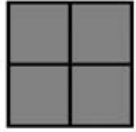

Perimeter $=8$

Area $=4$

$\mathrm{P} / \mathrm{A}=2$

Perimeter $=16$

Area $=16$

$\mathrm{P} / \mathrm{A}=1$

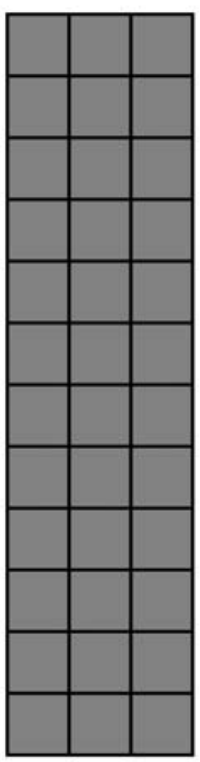

Perimeter $=30$

Area $=36$

$\mathrm{P} / \mathrm{A}=0.83$

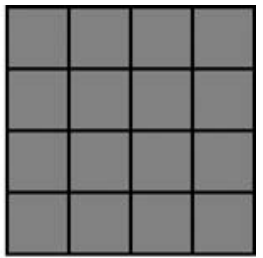

Figure 1. Fencing considerations: (A) as the area enclosed by a fence increases, the perimeter length increases at a lower rate, and (B) perimeter length of a square plot is shorter than a rectangular plot enclosing the same area.

because they have longer perimeters (Fig. 1B). Finally, $80-85 \%$ of the cost of materials of most fences is in the corner and end systems; therefore, an effort should be made to minimize these.

We designed a computer model to assist with determining if fencing is economically feasible for reducing deer damage and, if so, which fence design would be optimal (VerCauteren et al. 2006). Our interactive model provides economic analyses and predicts the scenarios associated with fencing relative to area and perimeter of the protected plot, value and percentage of crop damaged annually prior to fencing, cost of the fence, and efficacy of the fence. Users of the model can easily adjust the above variables to fit their individual situations and needs. By running a series of simulations, users can answer questions directly related to the economics associated with different fence designs for their situation.

\section{Negative Impacts}

Fences can effectively protect human commodities; however, they can have negative long-term impacts on a variety of wildlife. For example, a fence can obstruct the natural migration and daily movements of deer and other wildlife (Owen and Owen 1980, Foster and Humphrey 1995, Clevenger et al. 2001) and the implications of disrupting these movements should be considered. Nielson et al. (1997) found that even a fence with occasional openings reduced deer emigration and immigration. Likewise, large-scale barrier fences in Africa, developed to control the spread of foot and mouth disease among domestic livestock, have had detrimental effects on wildlife migrations (Owen and Owen 1980).

Deer occasionally become entangled in fences or collide with them when attempting to pass over, through, or under (Goddard et al. 2001). Within a 5-year period following construction of a large enclosure, 15 deer and 1 elk were killed after colliding with a fence in Oregon (Bryant et al. 1993). Some birds, such as American kestrel (Falco sparverius Linnaeus) and blue grouse (Dendragapus obscurus Say) have also died from fence collisions (Bryant et al. 1993). Howard (1991) in a New Mexico study evaluating the effects of predator control fences on mule deer movements reported 1 death and at least 10 temporary entanglements on $19 \mathrm{~km}$ of fence.

Goddard et al. (2001) recommended increasing the visibility of fences to reduce ungulate and other wildlife collisions. When installing seasonal electric fences, attaching flagging tape every 10 $\mathrm{m}$ helps alert deer to the presence of the fence (McKillop and Sibly 1988).

\section{Permanent Fencing}

\section{Wire Mesh}

High, wire-mesh fences typically are constructed with the expectation of a long and effective lifespan (Isleib 1995). A common long-term fence design for deer exclusion or confinement is the 2.4- to $3.0-\mathrm{m}$ wire-mesh fence. Wire mesh is available in many different forms, including: woven wire, chain link, welded wire, "v" mesh, and rigid-mesh panels. Wire-mesh materials vary in weight, durability, expected lifespan, ease of construction, and cost.

Woven-wire fence was favored by survey respondents in Michigan and Wisconsin and considered the most effective for excluding deer (Isleib 1995). Quality wire-mesh fence materials cost approximately $\$ 10$ to $>\$ 20 / \mathrm{m}$ and can last $>30$ years (Curtis et al. 1994). Chain-link fence and wire fence panels are the most expensive with welded wire the least. Two lengths of $1.2-$ to $1.8-\mathrm{m}$ mesh fence, which is commonly available, often are erected one on top of the other, to attain a desired height of 2.4-3.6 m. Although the cost of woven wire is slightly higher than welded wire, it is more durable and is designed to be more effective in following the contours of the land; therefore, it is recommended over welded wire. Woven-wire fence made of 12.5-ga galvanized high-tensile steel appears to be an ideal fencing material for deer exclusion and containment. When manufactured with tension curves on horizontal wires, the fence material has elasticity to minimize harm to an animal impacting it and facilitates installation on uneven terrain (Bryant et al. 1993). Wire-mesh fence is available with wider spacing near the top rows and should be installed with the larger mesh spaces $(>0.19 \mathrm{~m})$ well above the height of an approaching deer, to discourage attempts at penetration.

Wire-mesh fence is used commonly to minimize wildlife-vehicle collisions along busy highways within migration corridors. A 2.4$\mathrm{m}$ wire-mesh fence along an interstate in Wyoming was effective 
in reducing collisions when used in conjunction with underpasses (Ward 1982). Clevenger et al. (2001) also reported success (80\% reduction in DVCs) when a $2.4-\mathrm{m}$ wire-mesh fence was erected along a highway in Banff National Park, Alberta, Canada. Lehnert and Bissonette (1997) reported that a 2.3-m woven-wire fence reduced deer grazing in an interstate right-of-way by $42 \%$.

Feldhamer et al. (1986) examined the efficacy of 2 fence designs for excluding deer including a $2.7-\mathrm{m}$ woven-wire fence and a 2.2$\mathrm{m}$ woven-wire fence with 2 additional strands of high-tensile wire on top along an interstate highway. When adjacent to forested areas, the $2.7-\mathrm{m}$ fence was more effective than the $2.2-\mathrm{m}$ fence, although on nonforested or level ground, efficacy between fences was similar. Deer rarely, if ever, attempted to jump the $2.7-\mathrm{m}$ fence, choosing instead to go under wherever possible. One difficultly encountered in the installation was minimal flexibility of the fence material, making it difficult to follow the contours of the ground, leaving gaps between the fence and the ground. A single strand of barbed wire or high-tensile wire strung below a fence is a simple solution to this problem (Bryant et al. 1993). Many fence construction problems can be solved initially by investing the extra time and money up front, using a bulldozer to clear and level a straight course for fence installation. This will improve the visibility of the fence and overall efficacy (Smith 1983, Palmer et al. 1985).

Due to the cost of supplies $(>\$ 5 / \mathrm{m})$ and installation $(>\$ 5 / \mathrm{m})$, wire-mesh fence often is practical only for high-value crops, orchards, airplane runways, busy highways, high-fenced shooting preserves, game farms, and areas with potential for extreme deer damage (Craven and Hygnstrom 1994). Although wire-mesh fence is more expensive than other fence materials, it can remain effective for $>30$ years (Byrne 1989, Bryant et al. 1993) with minimal maintenance, resulting in reasonable annual costs when amortized over the lifespan of the fence.

\section{Modified Woven-Wire Mesh}

In situations where an existing wire-mesh livestock fence is present, options are available for modifying it to effectively exclude deer. With minimal construction costs, multiple strands of hightensile wire or wire mesh can be added on extensions above the existing fence to increase overall height. Although electrified or barbed wire occasionally are installed above an existing fence, their added efficacy beyond smooth wire is questionable if leaping deer cannot receive negative stimuli before attempting to breach the fence.

Falk et al. (1978) evaluated the efficacy of a modified wovenwire fence that paralleled an interstate highway. The fence consisted of a $1.2-\mathrm{m}$ woven-wire fence topped by 5 high-tensile wires, with the top 2 on outriggers angled away from the interstate; overall fence height was $2.3 \mathrm{~m}$. They reported that only 6 deer crossed the highway in fenced areas while 271 crossed in unfenced areas. Of the 6 crossings, 4 deer crawled under the fence and 2 jumped over. When the fence was not maintained, its effectiveness dropped considerably. Howard (1991) tested whether a modified woven-wire fence that included barbed wire and electrified high-tensile wire would impact mule deer travel. $\mathrm{He}$ monitored the fence at established deer crossings and determined it to be $63 \%$ effective in impeding deer.

Multiple strands of high-tensile wire on outriggers or extensions can be added to livestock or pet fences to attain effective heights at a cost of $<\$ 2 / \mathrm{m}$. A modified wire-mesh fence is suitable for the protection of high-value crops if built to the height and wirespacing specifications mentioned in the wire-mesh fence section. A complete modified woven-wire fence design costs about $\$ 5-\$ 10 / \mathrm{m}$.

\section{Slanted Wire-Mesh Fence}

The slanted wire-mesh fence design is an alternative to vertical wire-mesh fence that deters jumping based on its 3-dimensional appearance because it would require a long and high jump to breach (Curtis et al. 1994). Jones and Longhurst (1958) found that approaching deer would attempt to go under or through fences that slanted toward them but rarely, if ever, did they jump over. Messner et al. (1973) reported successful exclusion from experimental plots with a slanted woven-wire fence design. Wire mesh that is $1.8-\mathrm{m}$ tall and installed at a $45^{\circ}$ angle to the ground results in a barrier that is approximately $1.3-\mathrm{m}$ tall and $1.35-\mathrm{m}$ wide, costing $\$ 2-\$ 5 / \mathrm{m}$. Problems associated with this design include increased space requirements, increased vegetation maintenance, and increased susceptibility to damage from heavy snow loads.

\section{Barbed-Wire Fence}

Barbed-wire fences, traditionally used for containing livestock, when built to adequate height and maintained, can be effective in eliminating or reducing deer damage to stored livestock feed (Schneidmiller 1988). They are appealing because of their low cost and availability of materials. With strand spacing of $<0.19 \mathrm{~m}$ and built 2- to 3-m high, barbed-wire can provide a cost-effective solution in some situations. Although one problem with constructing high fences with barbed wire is the increased probability of animals becoming entangled when attempting to penetrate the fence. Cost of materials for an 18-strand, $2.4-\mathrm{m}$ barbed-wire fence range from $\$ 2-\$ 4 / \mathrm{m}$.

\section{Electric Fences}

When considering electric fences, many factors should be examined, including voltage requirements, fence configuration, charge configuration, seasonal fences, and attractants. While wiremesh fences prevent the passage of deer by physically blocking them, electric fences typically rely on behavioral conditioning by administering a shock to approaching deer (Porter 1983, McKillop and Sibly 1988, Curtis et al. 1994). For successful deer control, a minimum charge of 3,000 volts should be used on hightensile wire and poly-type materials (Matschke et al. 1984, Duffy et al. 1988, Curtis et al. 1994).

Two basic configurations are used for charging an electric fence; an all-positive system or a positive/negative return system (Fig. 2). The all-positive system has a positive charge running through all wires with the soil acting to ground and complete the circuit when an animal contacts a wire. The benefit of this configuration is that the animal need contact only 1 wire while touching the ground to receive a shock. Drawbacks include the increased probability of vegetation shorting the system and that poorly-conductive soil or snow could insulate the animal, resulting in little or no negative reinforcement. Advancements in electrical energizers (low-impedance) have reduced problems with shortages attributed to vegetation (McAninch et al. 1983, Palmer et al. 1985). The 


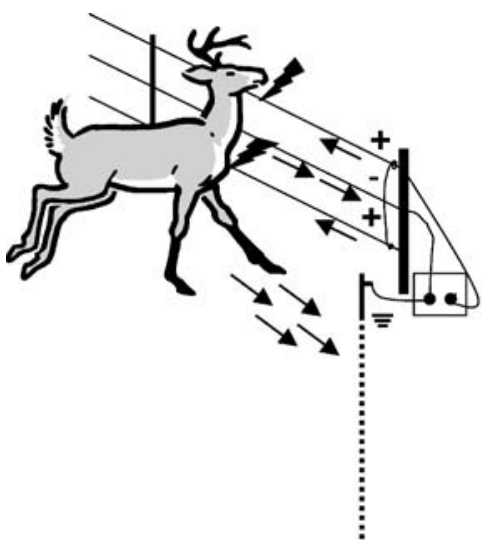

Positive/negative system

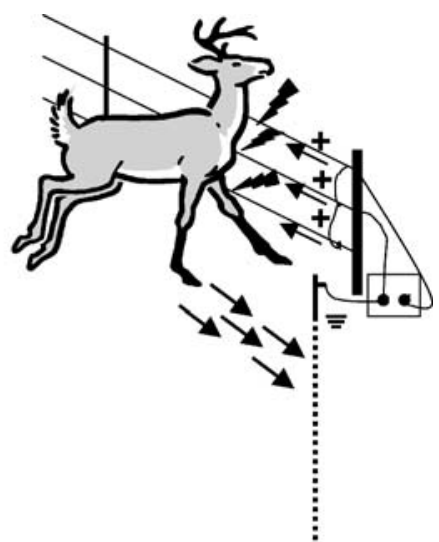

All positive system
Figure 2. To maximize efficacy related to environmental conditions, multistrand electric fences can be wired with both positively and negatively charged wires, or all wires positively charged.

positive/negative return system is a configuration that has alternating positive and negative wires. To complete the circuit and receive a shock, either a positive and negative wire, or a positive wire and the ground, must be contacted simultaneously. Benefits of this system include decreased chance of vegetation shorting the system, capability of shocking an animal not in contact with the ground, and fewer problems associated with poor soil conductivity. The insulating effects of hollow deer hair as well as the minimal grounding surface area of hooves may moderate the shock of electric fences (G. Wright, The Wright Place, personal communication). Quite often, if a deer is partially through an electric fence before receiving a shock, it will continue through (McKillop and Sibly 1988, Curtis et al. 1994). Historically, although not advocated herein due to safety concerns, barbed-wire fences were electrified and charged with relatively low voltages (approximately 700 volts); the barbs may have helped to penetrate a deer's coat and transfer electricity (McAtee 1939).

\section{High-Tensile Electric Fence}

A fence design that has been used successfully in New Zealand for nearly 40 years incorporates stretched 12.5 -ga high-tensile wire electrified with a high-voltage energizer. Numerous field trials have shown that deer damage can be nearly eliminated with this type of fence (Tierson 1969, Brenneman 1982, Palmer et al. 1985). The first high-tensile design reported on is the $1.5-\mathrm{m}$ Penn State 5-wire electric fence, (Fig. 3A), (Palmer et al. 1985). A 6- to 7 -wire, $1.5-\mathrm{m}$ high configuration with alternating positive and negative high-tensile wires creates a better physical barrier and is more commonly used today in deer damage management (S. E. Hygnstrom, University of Nebraska, personal observation).

Other high-tensile fence designs include the slanted multistrand (Fig. 3B) and the offset, also known as the New Hampshire Figure-4 (Fig. 3C). The offset is 2 simple electric fences set up parallel to each other with wires at staggered heights (Brenneman 1982, Palmer et al. 1985). Palmer et al. (1985) compared the efficacy of 5 fence designs, including Penn State 5-wire electric, slanted high-tensile electric, modified welded-wire with outriggers, offset, and slanted welded wire. Deer penetrated all fence designs except the Penn State 5-wire electric.
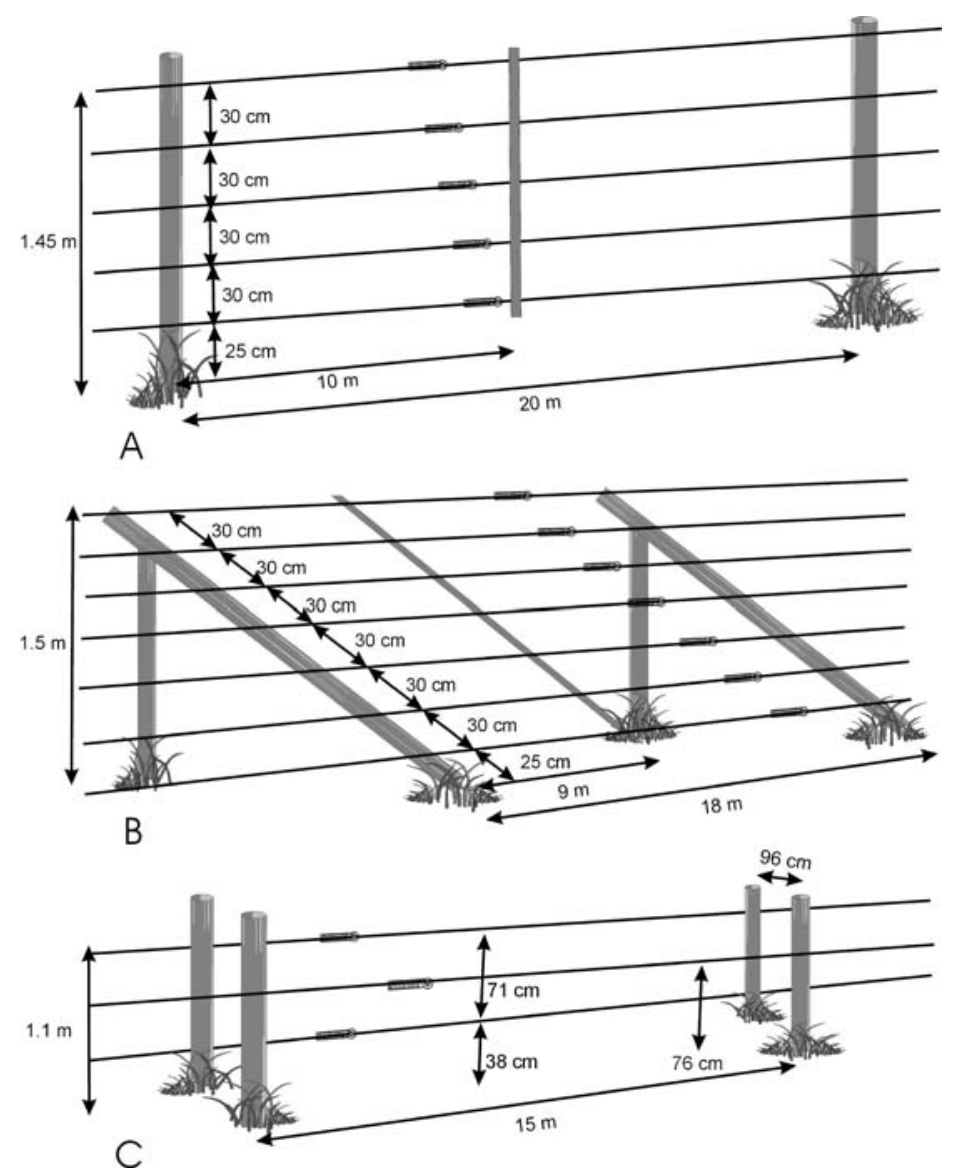

Figure 3. Three high-tensile fence designs including: (A) Penn State 5, (B) slanted multi-strand, and (C) offset.

Brenneman (1982) conducted a study with 2 high-tensile electric fence designs in hardwood clearcuts, examining their efficacy for reducing browse damage to seedlings. One plot was enclosed with an offset, another with a Penn State 5-wire electric. Browse rates of $>33 \%$ were detected in control plots, while fenced plots received no detectable browse. Though both fences were penetrated, the Penn State 5-wire electric was breached less frequently. Ellingwood et al. (1985) conducted a survey of farmers who had installed 7-strand slanted fences $(n=12)$ and reported that $75 \%$ of them felt they performed excellently and $100 \%$ would invest in deer fence again. Some penetrations should be expected; $90 \%$ of these fences were said to have been penetrated by deer. The 7-strand slanted fence design is considered an effective barrier in reducing damage even under high deer pressure (McAninch et al. 1983, Craven and Hygnstrom 1994). Howard (1991) evaluated the impact of a 15-km-long, 7-strand, 1.5-m electric fence on mule deer movements at fence crossings for 4 years and found the fence to be $87 \%$ effective at excluding mule deer.

The efficacy of any fence can vary greatly from one setting to another. The additional alfalfa produced by the exclusion of deer by a Penn State 5 -wire electric fence paid for the fence in 1 season (Palmer and Wingard 1983). Conversely, Fagerstone and Clay (1997) reported that even with a 1.8-m, 9-strand electric fence installed to protect crops in Wisconsin, a landowner suffered crop damage of $>\$ 5,000 /$ year. The problem was solved when 21 deer that were accustomed to penetrating the fence were removed. 
Though high-tensile electric fences may not offer the same level of protection as wire-mesh fences of comparable height, they are less expensive. Craven and Hygnstrom (1994) reported slanted and upright high-tensile fences to be suitable for protection of orchards, large vegetable gardens, and other fields under moderate to high deer pressure, while the offset electric may only be suitable for smaller fields $(<1.6 \mathrm{ha})$ under moderate deer pressure. Average costs of materials to construct a high-tensile electric fence range from $\$ 2-\$ 5 / \mathrm{m}$. Maintenance requirements include frequent inspection, seasonal tensioning of wire, and suppression of vegetation. Although fallen trees will occasionally down a fence, the elasticity of the high-tensile wires often keeps them from breaking (Brenneman 1983).

\section{Semi-Permanent or Temporary Fencing}

The above-mentioned fence designs are most often considered long-term installations, providing a level of protection that may not be needed in all situations. Agricultural crops such as corn, sorghum, soybeans, and vegetables, as well as stored livestock feed and orchards may require only seasonal protection. A variety of portable fences may be more practical and can be installed just prior to when damage is likely to occur.

\section{Seasonal Electric Fence}

Seasonal fences typically are less expensive and visually obtrusive than long-term fences, but they also generally provide less protection and have a shorter lifespan. Though effective at containing livestock, the traditional electric fence for livestock consisted of a 17-ga smooth steel wire hung between plastic insulators on light-duty steel or fiberglass posts charged by a simple energizer and would provide minimal protection against motivated deer. Many variations of this fence design have appeared over the years, resulting in more effective and longerlasting barriers (Kinsey 1976, Hygnstrom and Craven 1988, Jordan and Richmond 1992).

\section{Polytape and Polyrope}

Polytape and polyrope electric fences incorporate conductive wires into synthetic ribbons or ropes. The materials are durable, easy to work with, and their cost is comparable to traditional electric fences. One benefit is their high visibility, which may minimize animal-fence collisions (Hygnstrom and Craven 1988). With the increased surface area provided by poly-fences, the application of attractants or repellents is also more efficient. Problems with vegetation shorting out these fences is minimized through the use of low-impedance energizers and the option of running positive and negative charges on alternating strands.

Hygnstrom and Craven (1988) reported a single-strand, 0.6-m polytape fence effectively reduced deer damage by $90 \%$ in small corn fields ( $<6$ ha). Seamans and VerCauteren (2006) evaluated a 1.3-m, 5-strand polyrope fence for keeping deer from bait sites. The fence was $99 \%$ effective, although 1 yearling doe continually penetrated the fence. A similar fence was evaluated with deer motivated in 3 ways, by putting members of family groups on the opposite side, by luring with food, and through human presence (K. C. VerCauteren, National Wildlife Research Center, unpublished data). The 1.3-m, 5-strand was relatively ineffective; however, efficacy increased as the number of strands and overall height increased.

Poly-material fences are quite versatile and show varying degrees of efficacy. Single or double-strand fences can be constructed at costs of $<\$ 2 / \mathrm{m}$ and will protect small fields seasonally (Craven and Hygnstrom 1994). Because of the reduced conductivity of poly-tape wire, you can only power up to $0.4 \mathrm{~km}$ of fence $(\approx 15$ ha). Long-term poly-fence installations can protect larger areas of high-value crops or even airports at costs ranging from $\$ 5-\$ 10 / \mathrm{m}$, though exclusion is not $100 \%$.

\section{Attractant/Repellent-Laced Fences}

Under the right conditions, a simple wire, polyrope, or polytape fence with the addition of an attractant or a repellent can be effective for deer exclusion. Thinned peanut butter applied directly to poly-rope or poly-tape at the height of a deer's nose is as effective, less expensive, and easier (Porter 1983; Hygnstrom and Craven 1988). Although effective, the addition of aluminum foil flags increases maintenance, materials, and application time with little or no increase in efficacy (S. E. Hygnstrom, University of Nebraska, personal observation). The use of attractants increases aversion by encouraging deer to touch an electrified fence (Jordan and Richmond 1992). Porter (1983) protected apple seedlings using this fence with nearly $50 \%$ less browse damage to protected seedlings. Hygnstrom and Craven (1988) evaluated 3 0.6-m, single-strand electric fence designs and 2 repellents. Electric fence designs included a 17-gauge wire coated with a peanut butter mixture, a polytape design, and a foil ribbon fence product. They found no differences in efficacy among fence types, but fields protected by fences sustained less damage than unprotected fields and those protected with just repellents.

The use of repellents in conjunction with electric fences also shows promise but has not been rigorously tested. Jordan and Richmond (1992) compared the efficacy between 1.5-m, 3-strand electric fences, 1 with an attractant (peanut butter), and the other with a repellent (ammonium soaps of higher fatty acids). The fence with the repellent provided the greatest protection. Attractant- and repellent-laced fences can be effective in protecting small plots $(<2 \mathrm{ha})$ under moderate deer pressure at a cost of $<\$ 2 / \mathrm{m}$ (Porter 1983, Craven and Hygnstrom 1994).

\section{Alternative Need and Designs}

In addition to seasonal electric fences, many materials can be used to protect small areas for short periods of time. For example, stored feed for livestock should be protected during the late winter when natural foods are not available to deer. Protection can be achieved with wire or wooden fence panels. Wire fence panels may be better because they are durable, longer lasting, and easier to work with. Protection also can be provided by various types of plastic barriers or coverings. Polypropylene snow fence, plastic sheeting, and tarps are lightweight, easy to work with, can be used to wrap stored feed in little time, and provide good season-long results. A polypropylene mesh fence material that is produced in various strengths and heights is also available. Rosenberry et al. (2001) reported no detectable deer damage to corn and soybeans within exclosures constructed of a $2.4-\mathrm{m}$ polypropylene fence. It is lightweight, easy to erect, comes in heights up to $4.9 \mathrm{~m}$, and is quite durable. 
Residents in suburban and rural areas who experience deer damage to their landscaping also have specific fence needs. Many municipalities have ordinances that preclude the use of electric fences and electric and wire-mesh fences may not be aesthetically pleasing. A polypropylene mesh fence may be warranted where aesthetics are important (Rosenberry et al. 2001). Beringer et al. (2003) evaluated a $1.5 \mathrm{~m}, 5$-strand monofilament fence that was unobtrusive, though it performed poorly. Monofilament mesh fence has not been evaluated as a deer barrier but may work well to protect landscaping without detracting from aesthetics.

\section{Gates}

A fence is only as strong as its weakest link, which in many cases is the gate, primarily because they must be closed to be effective. Gates must be at least as tall as the fence and easy to use. Experimental alternatives to traditional gates are being developed and tested. Reed et al. (1974) examined the efficacy of modified cattle guards for preventing mule deer crossings and reported limited success. Bashore and Bellis (1982) reported virtual elimination of deer problems through the installation of a $2.4-\mathrm{m}$ fence with cattle guards. More recently, Belant et al. (1998) evaluated cattle guards and reported them to be $95-98 \%$ effective. Other modified versions, including bridge grating (Peterson et al. 2003) and electrified mats (D. Nolte and T. Seamans, National Wildlife Research Center, unpublished data) are under evaluation.

When constructing effective deer fences, it may also be important to consider a means of removing animals that have breached a fence. One-way gates have been used along highway right-of-way fences and have been effective in allowing deer passage out of the right-of-way, and reducing DVCs (Reed et al. 1974, Ludwig and Bremicker 1983, Lehnert and Bissonette 1997).

\section{Summary}

Important considerations for determining the best fence design for a specific deer-management situation include level of protection required, ability and motivation of the deer to penetrate, economics, and possible negative effects. Use of deer-exclusion

\section{Literature Cited}

Arnold, D. A., and L. J. Verme. 1963. Ten year's observation of an enclosed deer herd in Northern Michigan. North American Wildlife Conference 28: 422-430.

Bartlett, I. H., and A. P. Boyce. 1954. Deer-proof fences. Michigan Department of Conservation-Game Division, Report No. 1199.

Bashore, T. L., and E. D. Bellis. 1982. Deer on Pennsylvania airfields: problems and means of control. Wildlife Society Bulletin 10:386-388.

Bashore, T. L., W. M. Tzilkowski, and E. D. Bellis. 1985. Analysis of deervehicle collision sites in Pennsylvania. Journal of Wildlife Management 49: 769-774.

Belant, J. L., T. W. Seamans, and C. P. Dwyer. 1998. Cattle guards reduce white-tailed deer crossings through fence openings. International Journal of Pest Management 44:247-249.

Beringer, J., K. C. VerCauteren, and J. J. Milspaugh. 2003. Evaluation of an animal-activated scarecrow and a monofilament fence for reducing deer use of soybean fields. Wildlife Society Bulletin 31:492-498.

Brenneman, R. 1982. Electric fencing to prevent deer browsing on hardwood clearcuts. Journal of Forestry 80:660-661.

Brenneman, R. 1983. Use of electric fencing to prevent deer browsing in Allegheny hardwood forests. Proceedings of the Eastern Wildlife Damage Control Conference 1:97-98.

Bryant, L. D., J. W. Thomas, and M. M. Rowland. 1993. Techniques to fencing may be only part of the solution to a deer damage issue. For the chosen fence design to remain effective, specific deer that are persistently penetrating a fence should be removed to prevent other deer from learning this behavior. Deer exclusion by fencing is not always the solution for controlling deer damage. An integrated approach will increase the overall efficacy of reducing deer damage.

When tolerance for deer penetration is low (i.e., even light damage is unacceptable during the life of the fence) $a \geq 3.0$ wovenwire fence should be the only practiced option. If complete exclusion is not necessary and the cost of fence is an issue, a multistrand, electrified, high-tensile wire fence may be sufficient. For seasonal protection, an affordable and easily installed, electric poly-fence may be a reasonable alternative. Various factors must be considered to determine which style of fence is appropriate for the management goal. An understanding of available options will allow a thorough comparison and facilitate the decision-making process. See VerCauteren et al. (2006) for a computer-simulation model designed to aid in assisting in fence selection relative to management goals and scenarios.

The need for effective management tools to reduce damage caused by deer is increasing. High white-tailed deer densities have the potential to lead to disease outbreaks, increased DVCs, and increased problems in urban areas. Most of the literature reviewed has been directed at excluding animals although effective containment is also important. Few rigorous tests of the efficacy of different fence designs under varying levels of motivation have been conducted. Thus, a representative level of efficacy for any specific fence design is difficult to establish due to the many variables contributing to how an animal will respond to a particular fence design at any time, under any level of motivation.

\section{Acknowledgments}

We thank J. Gilsdorf, N. Seward, and G. Phillips for their reviews which improved the manuscript. The National Wildlife Research Center provided funding to complete this review.

construct New Zealand elk-proof fence. United States Department of Agriculture, General Technical Report PNW-GTR-313, Forest Service, Pacific Northwest Research Station, Portland, Oregon, USA.

Byrne, A. E. 1989. Experimental applications of high-tensile wire and other fencing to control big game damage in Northwest Colorado. Proceedings of the Great Plains Wildlife Damage Control Workshop 9:109-115.

Caslick, J. W. 1980. Deer-proof fences for orchards: a new look at economic feasibility. Proceedings of the Vertebrate Pest Control Conference 9:161162.

Caslick, J. W., and D. J. Decker. 1979. Economic feasibility of a deer-proof fence for apple orchards. Wildlife Society Bulletin 7:173-175.

Clevenger, A. P., B. Chruszcz, and K. E. Gunson. 2001. Highway mitigation fencing reduces wildlife-vehicle collisions. Wildlife Society Bulletin 29:646653.

Conover, M. R. 2002. Resolving wildlife conflicts: the science of wildlife damage management. Lewis, Boca Raton, Florida, USA.

Conover, M. R., and D. J. Decker. 1991. Wildlife damage to crops: perceptions of agricultural and wildlife professionals. Wildlife Society Bulletin 19:46-52.

Craven, S. E. 1983. New directions in deer damage management in Wisconsin. Proceedings of the Eastern Wildlife Damage Control Conference 1:65-67.

Craven, S. R., D. J. Decker, S. E. Hygnstrom, and W. F. Siemer. 1992. Deer. 
Survey use and landowner tolerance in wildlife damage management. North American Wildlife and Natural Resources Conference 57:75-88.

Craven, S. R., and S. E. Hygnstrom. 1994. Deer. Pages D25-40 in S. E. Hygnstrom, R. M. Timm, and G. E. Larson, editors. Prevention and Control of Wildlife Damage. University of Nebraska Cooperative Extension, Lincoln, Nebraska, USA.

Curtis, P. D., M. J. Farigone, and M. E. Richmond. 1994. Preventing deer damage with barrier, electrical, and behavioral fencing systems. Proceedings of the Vertebrate Pest Control Conference 16:223-227.

DeNicola, A. J., K. C. VerCauteren, P. D. Curtis, and S. E. Hygnstrom.. 2000. Managing white-tailed deer in suburban environments. Cornell University Cooperative Extension, Ithaca, New York, USA.

Dolbeer, R. A., S. E. Wright, and E. C. Cleary. 2000. Ranking the hazard level of wildlife species to aviation. Wildlife Society Bulletin 28:372-378.

Duffy, B., B. McBratney, B. Holland, and D. Colvert. 1988. Fences. United States Department of Interior, Bureau of Land Management and United States Department of Agriculture, Forest Service-Technology and Development Program.

Ellingwood, M. R., J. B. McAninch, and M. J. Farigone. 1985. Current status of deer fencing in the Northeast. Proceedings of the Eastern Wildlife Damage Control Conference 2:180-185.

Fagerstone, K. A., and W. H. Clay. 1997. Overview of USDA Animal Damage Control efforts to manage overabundant deer. Wildlife Society Bulletin 25: 413-417.

Falk, N. W., H. B. Graves, and E. D. Bellis. 1978. Highway right-of-way fences as deer deterrents. Journal of Wildlife Management 42:646-650.

Feldhamer, G. A., J. E. Gates, D. M. Harman, A. J. Loranger, and K. R. Dixon. 1986. Effects of interstate highway fencing on white-tailed deer activity. Journal of Wildlife Management 50:497-503.

Fitzwater, W. D. 1972. Barrier fencing in wildlife management. Proceedings of the Vertebrate Pest Control Conference 5:49-55.

Flyger, V., and T. Thoerig. 1962. Crop damage caused by Maryland deer. Proceedings of the Southeastern association of game and fish commissioners 16:45-52.

Foster, M. L., and S. R. Humphrey. 1995. Use of highway underpasses by Florida panthers and other wildlife. Wildlife Society Bulletin 23:95-100.

Gallagher, G. R., and R. H. Prince. 2003. Negative operant conditioning fails to deter white-tailed deer foraging activity. Crop Protection 22:893-895.

Goddard, P. J., R. W. Summers, A. J. MacDonald, C. Murray, and A. R. Fawcett. 2001. Behavioural responses of red deer to fences of 5 different designs. Applied Animal Behavioural Science 73:289-298.

Howard, V. W., Jr. 1991. Effects of electric predator-excluding fences on movements of mule deer in pinyon/juniper woodlands. Wildlife Society Bulletin 19:331-334.

Hygnstrom, S. E., and S. R. Craven. 1988. Electric fences and commercial repellents for reducing deer damage in cornfields. Wildlife Society Bulletin 16:291-296.

Isleib, J. 1995. Deer exclusion efforts to reduce crop damage in Michigan and Northeast Wisconsin. Great Plains Wildlife Damage Control Workshop 12: 63-69.

Jones, M. B., and W. M. Longhurst. 1958. Overhanging deer fences. Journal of Wildlife Management 22:325-326.

Jordan, D. M., and M. E. Richmond. 1992. Effectiveness of a vertical 3-wire electric fence modified with attractants or repellents as a deer exclosure. Proceedings of the Eastern Wildlife Damage Control Conference 5:44-47.

Kaneene, J. B., C. S. Bruning-Fann, L. M. Granger, R. Miller, and B. A. PorterSpalding. 2002. Environmental and farm management associated with tuberculosis on cattle farms in northeastern Michigan. Journal of the American Veterinary Medical Association 221:837-842.

Kilpatrick, H. J., and A. M. LaBonte. 2003. Deer hunting in a residential community: the community's perspective. Wildlife Society Bulletin 31:340348.

Kinsey, C. 1976. Minnesota Department of Natural Resources. Tests of 2 electric deer barrier forms. Minnesota Wildlife Resources Quarterly 36:122137.

Lehnert, M. E., and J. A. Bissonette. 1997. Effectiveness of highway crosswalk structures at reducing deer-vehicle collisions. Wildlife Society Bulletin 25: 809-818.

Loomis, F. D. 1975. Control of white-tailed deer in field and orchard. Proceedings of the Great Plains Wildlife Damage Control Workshop 2:5161.

Ludwig, J., and T. Bremicker. 1983. Evaluation of 2.4-m fences and one-way gates for reducing deer-vehicle collisions in Minnesota. Transportation Research Record 913:19-22.

Marsh, R. E., A. E. Koehler, and T. P. Salmon. 1990. Exclusionary methods and materials to protect plants from pest mammals-a review. Proceedings of the Vertebrate Pest Conference 14:174-180.

Matschke, G. H., D. S. deCalesta, and J. D. Harder. 1984. Crop damage and control. Pages 647-654 in L. K. Halls, editor. White-tailed deer: ecology and management. Stackpole Books, Harrisburg, Pennsylvania, USA.

McAninch, J. B. 1986. Recent advances in repellents and fencing to deter deer damage. Proceedings of the New England Fruit Meetings 86:31-39.

McAninch, J. B., R. Winchcombe, and M. Ellingwood. 1983. Fence designs for deer control: a review and the results of recent research in southeastern New York. Proceedings of the Eastern Wildlife Damage Control Conference 1: 101.

McAtee, W. L. 1939. The electric fence in wildlife management. Journal of Wildlife Management 3:1-13.

McKillop, I. G., and R. M. Sibly. 1988. Animal behaviour at electric fences and the implications for management. Mammal Review 18:91-103.

McKnight, T. L. 1969. Barrier fencing for vermin control in Australia. The Geological Review 59:330-347.

Messner, H. E., D. R. Dietz, and E. C. Garrett. 1973. A modification of the slanting deer fence. Journal of Range Management 26:233-234.

Miller, M. W., M. A. Wild, and E. S. Williams. 1998. Epidemiology of chronic wasting disease in captive Rocky Mountain elk. Journal of Wildlife Diseases 34:532-538.

Miller, W. M., E. S. Williams, N. T. Hobbs, and L. L. Wolfe. 2004. Environmental sources of prion transmission in mule deer. Emerging Infectious Diseases 10:1003-1006.

Nielson, C. K., S. J. Nelson, and W. F. Porter. 1997. Emigration of deer from a partial enclosure. Wildlife Society Bulletin 25:282-290.

Owen, M., and D. Owen. 1980. The fences of death. African Wildlife 34:25-27.

Palmer, W. L., J. M. Payne, R. G. Wingard, and J. L. George. 1985. A practical fence to reduce deer damage. Wildlife Society Bulletin 13:240-245.

Palmer, W. L., and R. G. Wingard. 1983. Deer damage control in Pennsylvania agriculture. Proceedings of the Eastern Wildlife Damage Control Conference 1:75-76.

Peterson, M. N., R. R. Lopez, N. J. Silvy, C. B. Owen, P. A. Frank, and A. W. Braden. 2003. Evaluation of deer-exclusion grates in urban areas. Wildlife Society Bulletin 31:1198-1204.

Phillips, M., C. G. Forshey, G. B. White, and M. E. Richmond. 1987. The economic impact of wildlife damage on Hudson Valley orchards. Proceedings of the Eastern Wildlife Damage Control Conference 3:66-82.

Porter, W. F. 1983. A baited electric fence for controlling deer damage to orchard seedlings. Wildlife Society Bulletin 11:325-329.

Puglisi, M. J., J. S. Lindzey, and E. D. Bellis. 1974. Factors associated with highway mortality of white-tailed deer. Journal of Wildlife Management 38: 799-807.

Purdy, K. G., W. F. Siemer, G. A. Pomerantz, and T. L. Brown. 1987. Deer damage control preferences and use decisions of New York orchardists. Proceedings of the Eastern Wildlife Damage Control Conference 3:118-127.

Reed, D. F., T. M. Pojar, and T. N. Woodard. 1974. Mule deer responses to deer guards. Journal of Range Management 27:111-113.

Rhyan, J. C. 2000. Brucellosis in terrestrial wildlife and marine mammals. Pages 161-184 in C. Brown, and C. Bolin, editors. Emerging diseases of animals. American Society of Mammalogy. Washington, D.C., USA.

Rosenberry, C. S., L. I. Muller, and M. C. Conner. 2001. Movable, deer-proof fencing. Wildlife Society Bulletin 29:754-757.

Seamans, T. W., and K. C. VerCauteren. 2006. Evaluation of ElectroBraid ${ }^{\mathrm{TM}}$ fencing as a white-tailed deer barrier. Wildlife Society Bulletin 34:8-15.

Sauer, P. R. 1984. Physical characteristics. Pages 73-90 in L. K. Halls, editor. White-tailed deer: ecology and management. Stackpole Books, Harrisburg, Pennsylvania, USA.

Schmitt, S. M., S. D. Fitzgerlad, T. M. Cooley, C. S. Bruning-Fann, L. Sullivan, D. Barry, T. Carlson, R. B. Minnis, J. B. Payeur, and J. Sikarskie. 1997. Bovine tuberculosis in free-ranging white-tailed deer from Michigan. Journal of Wildlife Diseases 33:749-758.

Schneidmiller, J. F. 1988. Fencing methods to control big game damage to stored crops in Wyoming. Proceedings of the Great Plains Wildlife Damage Control Workshop 8:217-221.

Smith, D. 1983. Deer control using 5 strand vertical fence. Proceedings of the Eastern Wildlife Damage Control Conference 1:97-98.

Steger, R. E. 1988. Consider using electric powered fences for controlling 
animal damage. Proceedings of the Great Plains Wildlife Damage Control Workshop 8:215-216.

Tanner, G., and R. W. Dimmick. 1983. An evaluation of a method for reducing white-tailed deer depredations on soybeans in Western Tennessee. Proceedings of the Eastern Wildlife Damage Control Conference 1:71-73.

Tierson, W. C. 1969. Controlling deer use of forest vegetation with electric fences. Journal of Wildlife Management 33:922-926.

VerCauteren, K. C. 2003. The deer boom: discussions on population growth and range expansion of the white-tailed deer. Pages 15-20 in G. Hisey and K. Hisey, editors. Bowhunting records of North American white-tailed deer, Second edition. The Pope and Young Club, Chatfield, Minnesota, USA.

VerCauteren, K. C., M. J. Lavelle, and S. E. Hygnstrom. 2006. A simulation model for determining cost-effectiveness of fences for reducing deer damage. Wildlife Society Bulletin 34:16-22.

Ward, A. L. 1982. Mule deer behavior in relation to fencing and underpasses on Interstate 80 in Wyoming. Transportation Research Record 859.

Wywialowski, A. P. 1996. Wildlife damage to field corn in 1993. Wildlife Society Bulletin 24:264-271.

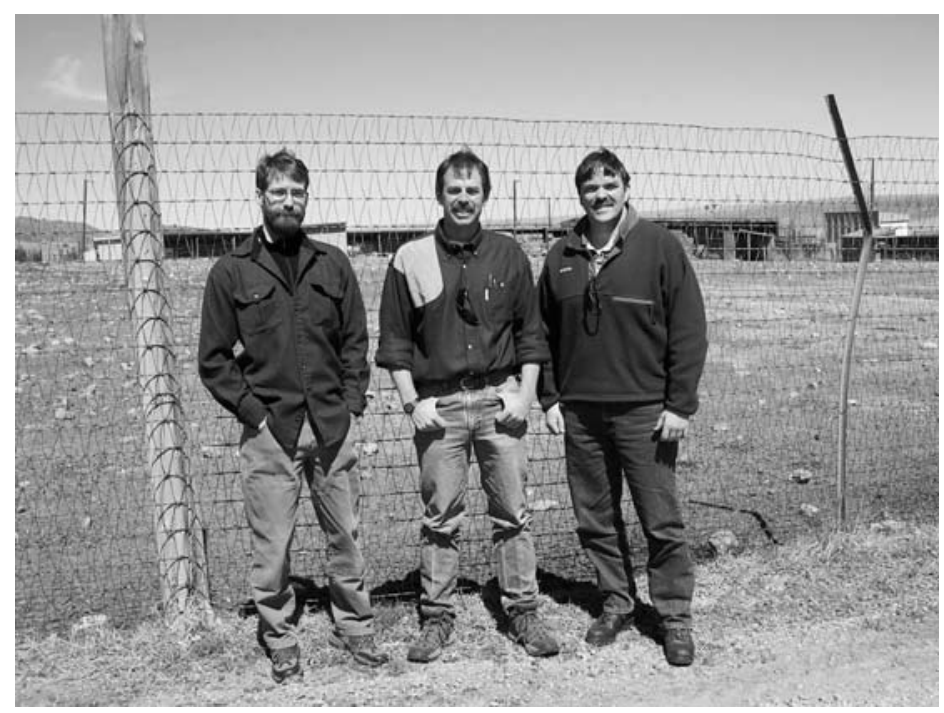

Kurt C. VerCauteren (center) is the Chronic Wasting Disease Project Leader for the Wildlife Disease Research Program of the National Wildlife Research Center. He received his B.S. from the University of WisconsinStevens Point, and M.S. and Ph.D. from the University of Nebraska-Lincoln. Kurt is a Certified Wildlife Biologist and has been on the board of the Wildlife Damage Management Working Group, served as Secretary of the Colorado Chapter of the Wildlife Society, and as President and Secretary of the Nebraska Chapter. His current research involves devising means to reduce transmission and to manage Chronic Wasting Disease and Bovine Tuberculosis in wild and captive cervids. Michael J. Lavelle (left) is a Biological Technician for the Wildlife Disease Research Program of the National Wildlife Research Center. He received his B.S. from the University of Nebraska-Lincoln. His research focuses on interactions of cervids and associated risk of disease transmission. Scott E. Hygnstrom (right) is a professor in the School of Natural Resources at the University of NebraskaLincoln specializing in wildlife damage management. He received his B.S. from the University of Wisconsin-River Falls, M.S. from the University of Wisconsin-Stevens Point, and Ph.D. from the University of WisconsinMadison. Scott is a Certified Wildlife Biologist and is a past-chair of the Wildlife Damage Management Working Group. 